\title{
The Shifting Landscape of International Practicum in Social Work Education
}

\author{
Wasif Ali, $\mathrm{PhD}$ \\ Faculty of Social Work, University of Calgary, Canada \\ Tel: 1-250-899-9417_E-mail: wasif.ali1@ucalgary.ca
}

Julie L. Drolet, $\mathrm{PhD}$ (Corresponding author)

Faculty of Social Work, University of Calgary, Canada

Tel: 1-780-492-1594Ｅ-mail: jdrolet@ucalgary.ca

Kamal Khatiwada, MSW student, BHSc.

Faculty of Social Work, University of Calgary, Canada

E-mail: kamal.khatiwada@ucalgary.ca

Emmanuel Chilanga, $\mathrm{PhD}$

Faculty of Social Work, University of Calgary, Canada

E-mail: emmanuel.chilanga@ucalgary.ca

Mohammed Nurudeen Musah, PhD student

Faculty of Social Work, University of Calgary, Canada

E-mail: mohammed.musah@ucalgary.ca

Received: October 29, 2021 Accepted: January 12, 2022 Published: January 28, 2022

doi:10.5296/ijsw.v9i1.19129 URL: https://doi.org/10.5296/ijsw.v9i1.19129 


\title{
II Macrothink \\ International Journal of Social Work \\ ISSN 2332-7278 \\ 2022, Vol. 9, No. 1
}

\begin{abstract}
International practicum, or international field placements, create opportunities for social work students to address global social challenges in an international setting and prepare for social work practice. The landscape of international practica in social work has evolved and shifted over the last two decades. This article reports on the findings of a literature review that was conducted to understand how international practicum has changed over time. The study established search criteria that led to the inclusion of 70 publications, 16 in the first decade (2000 to 2010) and 54 in the second decade (2011 to 2020) utilizing the web of Science and Social Work Abstracts, as well as specific searches conducted on the University of Calgary Library Database, EBSCO host, ProQuest, and Google Scholar. The results of the literature review show that there were fewer publications in the first decade and the emphasis was on understanding international practicum and field models. During the second decade, the published literature on international practicum tripled, focusing predominantly on developing new field education models, engaging in critical reflection and theory, and how to create successful field placements for students through preparation, teaching, and discussion. International practicum opportunities are critical to fostering transformative learning in social work students, and post-secondary institutions will need to re-establish international field education programs after the COVID-19 pandemic.
\end{abstract}

Keywords: International practicum, international field placement, field education 


\section{The Shifting Landscape of International Practicum in Social Work Education}

Social work education around the world has recognized the importance of international social work and social development (Todd \& Drolet, 2020). Global social problems and challenges such as poverty, environmental degradation, the impacts of climate change, forced migration, and the global pandemic are some of the issues that have led to the recognition that social work has an important role and contribution to offer internationally (Zuchowski et al., 2019). According to Numann-Schwartz and Berger (2012), the Council for Social Work Education strongly emphasizes "preparing social workers to recognize the global context of social work practice" (p. 226). At the international level, international social work organizations such as the International Association of Schools of Social Work (IASSW) and the International Federation of Social Workers (IFSW) adopted the Global Agenda for Social Work and Social Development in 2010. The agenda identified four priority areas for action: promoting social and economic equalities, promoting dignity and worth of peoples, working towards environmental sustainability, and strengthening human relationships (Jones \& Truell, 2012). The social work profession is rising to meet global challenges by preparing the next generation of social workers with innovative and proactive approaches to address global issues in the 2020-2030 Global Agenda and the United Nations' Sustainable Development Goals.

Globalization and internationalization have impacted social work education, including field education and international social work (Lyons, 2006). Globalization is characterized by the: (1) expansion of local borders to involve social, political, and economic relationships, (2) increase in travel, migration, and immigration, (3) cultural infusion, (4) industrialization and urbanization, and (5) global liberalization and amalgamation of economic systems (Dominelli, 2010; Lyons, 2006). Internationalization refers to "cross-border flows - of students, staff, and knowledge - and international cooperation" (Tight, 2021, p. 54). Globalization and internationalization have created interdependency between world regions, and there is an increased need for international social work in this context (Healy \& Thomas, 2020). In the 21 st century, social work requires knowledge, skills, and an understanding of global social issues and global challenges due to the processes of globalization and global interdependence (Payne \& Askeland, 2016).

Many social work educators have advocated for integrating international social work values and content into social work education curricula (Pettys et al., 2005; Small et al., 2017). International social work can strengthen social work practice by assisting students to recognize the impact of imperialism, colonialism, and modernization (Hay et al., 2018; Nadan, 2017). Hong and Song (2010) emphasized that the social work profession has a responsibility to advance social work education by incorporating international social work. This may include training current and future generations of social work professionals to understand the importance of international social work through international practica (Caragata \& Sanchez, 2002).

Practicum, also known as field education, is the site where social work students gain hands-on experience and prepare themselves for professional practice. It is often recognized 
by students the most critical part of their social work education (Ali \& Drolet, 2021). Various terms are used to refer to experiential learning opportunities such as practicum, field placement, internship, fieldwork, and preceptorship. International practicum is defined as a social work field placement that occurs abroad (in another country), allowing students to experience social work in diverse practice contexts, multicultural settings, in order to learn about the values of international social work. An international practicum can provide opportunities for social work students to address global social challenges in an international setting and prepare for social work practice (Jönsson \& Flem, 2018; Matthew \& Lough, 2017).

International practica provide a valuable opportunity to the student and the host field agency through the exchange of knowledge and culture to advance benefits from mutual learning and sharing (Fox \& Hugman, 2019). International practicum has been found to benefit social work students in many ways; for example, students gain understanding of how the socio-economic and political issues impact different populations in different regions. This understanding enhances their skills and abilities to practice in diverse settings (Jönsson \& Flem, 2020; Pawar et al., 2004; Tesoriero, 2006). Students' exposure to diverse cultures and traditions improves their understanding of how social work values can be distinct in different world regions (Rankopo \& Osei-Hwedie, 2011). International practica have been found to improve students' knowledge, skills, and self-reflexivity to understand complex global issues, and to advocate for a more equitable and just society in a global context (Cleak et al., 2016).

Therefore, in the past two decades, the contexts in which international practica are offered have evolved and shifted. The review identified and raised several important points including the planning and organization of international placements in light of globalization, benefits and challenges of international practicum, intercultural learning, career outcomes, placement experiences, and innovative approaches to social work field education.

\section{Method}

The following procedure was used to identify the literature that has been used in this study. A systematic search strategy was designed to identify scholarly and peer-reviewed sources utilizing the web of Science and Social Work Abstracts, as well as specific searches conducted on the University of Calgary Library Database, EBSCO host, ProQuest, and Google Scholar. An iterative search using the combination of the following search terms was conducted: international social work practicum, social work field placement, OR field education OR practicum field study AND "social work*” AND international or global, Social work* AND international* AND field education*, International practicum* AND social work, AND anti-oppressive approach, International practicum AND social work and anti-colonial approach. Inclusion criteria were based on studies which were presented in English from January 1, 2000 to 2021 (table 1). To include more papers, which can help to find the most relevant evidence with regards to how international practicum has evolved and shifted over the past two decades, we included both peer and non-peer reviewed articles. Literature mining was conducted by six research assistants with support from three research team leaders. All records were screened by each research assistant according to the eligibility 
criteria. After reading titles and abstracts for their relevance, full papers were retrieved and downloaded to a personal computer. This was followed by a screening of full text articles. Each research assistant came up with papers and were compared. All missing papers were consolidated prior to review. Each research assistant identified common themes relating to trends in international practicum over the past two decades and the results were compared.

The results of the search also identified doctoral dissertations. The results of the literature search were evaluated by separating each article/book into the time frames of 2000-2010 and 2011-2020. The number of articles in each time period were counted, and the articles/book were compared for similarities and differences based on the results of the search.

The results of the literature review focus on the shifts in international practicum in the areas of student learning, placement experiences and outcomes, field models of practicum, innovations in international field education, curriculum on international social work, and critical reflection and theory.

Table 1. Search strategy

\begin{tabular}{|c|c|c|}
\hline Database & Keywords & Search Modifications \\
\hline EBSCO host & $\begin{array}{l}\text { - International practicum*AND social } \\
\text { work }\end{array}$ & - $\quad$ Peer Reviewed \\
\hline ProQuest & $\begin{array}{l}\text { - Field placement OR field education OR } \\
\text { practicum field study AND "social } \\
\text { work*" AND international or global }\end{array}$ & $\begin{array}{l}\text { - Journals } \\
\text { - Books }\end{array}$ \\
\hline Google Scholar & $\begin{array}{l}\text { - Social work* AND international* AND } \\
\text { field education* }\end{array}$ & $\begin{array}{l}\text { - } 2000-2010 \\
\text { - } 2011-2020\end{array}$ \\
\hline & $\begin{array}{l}\text { - International practicum* AND social } \\
\text { work, AND anti oppressive approach }\end{array}$ & \\
\hline Web of Science & $\begin{array}{l}\text { - International practicum AND social } \\
\text { work and anti-colonial approach }\end{array}$ & \\
\hline
\end{tabular}

\section{Results}

In total, 70 documents that included journal articles, books, and dissertations were retrieved and analyzed, 16 in the period of 2000-2010 and 54 during 2011-2020.

\subsection{International Field Placements: 2000-2010}

The review identified 16 documents in the published literature relating to international social work practica in the period between 2000 to 2010. Table 2 illustrates the topic areas of interest during this period. 
Table 2. Common study areas in 2000-2010

\begin{tabular}{|c|c|c|}
\hline $\begin{array}{l}\text { Study } \\
\text { (Year) }\end{array}$ & Author & Subject/Area \\
\hline 2000 & Khan \& Dominelli & $\begin{array}{l}\text { Impact of globalization on social work field education and social } \\
\text { work practice. }\end{array}$ \\
\hline \multirow{2}{*}{2002} & Razack & $\begin{array}{l}\text { Purpose, planning and nature of practicum and international student } \\
\text { exchanges. }\end{array}$ \\
\hline & $\begin{array}{l}\text { Caragata } \\
\text { Sanchez }\end{array}$ & $\begin{array}{l}\text { Globalization and new imperatives for international social work } \\
\text { education in North America. }\end{array}$ \\
\hline \multirow{2}{*}{2003} & Maidment & Challenges experienced by students on field placement. \\
\hline & Johnson & Internationalization of social work program. \\
\hline 2004 & $\begin{array}{l}\text { Pawar, Hanna \& } \\
\text { Sheridan }\end{array}$ & Challenges and opportunities in organizing social work placements. \\
\hline \multirow{2}{*}{2005} & Pettys et al. & $\begin{array}{l}\text { Field supervision models, information about participating students, } \\
\text { screening processes, and preparations. }\end{array}$ \\
\hline & Van-Wormer & $\begin{array}{l}\text { Globalization, oppression, social exclusion, human rights, harm } \\
\text { reduction, and restorative justice. }\end{array}$ \\
\hline \multirow{2}{*}{2006} & Lyon & Experience of Canadian social work practicum students in India. \\
\hline & Tesoriero & Reflective practice and cross-cultural competence in field education. \\
\hline \multirow{2}{*}{2007} & Barlow & $\begin{array}{l}\text { Globalization, international social work, trans-national practice, and } \\
\text { social work education. }\end{array}$ \\
\hline & Engstrom \& Jones & $\begin{array}{l}\text { Context of globalization, global problems and country-specific } \\
\text { interventions to address transnational problems. }\end{array}$ \\
\hline 2009 & Lough & $\begin{array}{l}\text { Effective administration of international social work field } \\
\text { placements. }\end{array}$ \\
\hline \multirow{3}{*}{2010} & Dominelli & $\begin{array}{l}\text { Globalization, social development, and implications for social work } \\
\text { practice. }\end{array}$ \\
\hline & Hong \& Song & $\begin{array}{l}\text { Glocalization approach to social work practice and addressing social } \\
\text { justice concerns. }\end{array}$ \\
\hline & Cwikel et al. & Global changes and social work practice. \\
\hline
\end{tabular}




\subsubsection{Student Learning, Practicum Experiences, and Outcomes}

In the 2000-2010 period, many authors provided a significant examination of international field placements. A number of articles focused on planning and organizing international placements for students (Pawar et al., 2004). Razack (2002) discussed the need to develop a support mechanism for effective international placements and create space for dialogue before, during and after placement in addition to the preparatory courses offered by some schools. Lough (2009) expressed concerns about the unidimensional nature of international exchanges. Critical questions were raised about the flow of exchanges from the Global North to Global South (e.g., developing countries or low-income countries), often calling for greater reciprocity. Critiques of imperialism, colonization, and their profound consequences, were raised as critical issues to be addressed by social work education programs (Johnson, 2003). Many authors called for improving field education processes with respect to international field placements (Tesoriero, 2006).

In the literature reviewed, the value and benefits of international practica for students were documented. International placements were found to be innovative and challenging for students (Maidment, 2003). International placements provided opportunities to learn about culture, community development, policy, and practice contexts. Furthermore, students learned how to address the challenges associated with culture shock and language differences. Engstrom and Jones (2007) identified five areas of learning for students in international placements: 1) culture and behavior, 2) comparative views of social welfare, 3) experiencing being different, 4) diverse contexts and social work practice, and 5) global response versus local responses. The benefits of international social work field education included an opportunity to develop intercultural skills and intercultural sensitivity (Tesoriero, 2006).

Many field education programs during the first decade were seeking to develop effective international placements for students. To do this, appropriate field supervision was needed and maintaining accountability over large geographical distances (Pawar et al., 2004). With the increase in rapid technological developments, many authors identified how technology could be used to address field supervision challenges by adopting videoconferencing. Further, some authors spoke of the need to develop protocols on confidentiality issues, especially in countries where ethical standards and guidelines were not developed (Pettys et al., 2005). To develop effective international field placements, it was suggested that international placements required systematic planning, preparation and orientation, beyond the few formal orientation sessions provided to students (Van-Wormer, 2005). The literature reflects lessons learned such as prior preparation, language skills training, and debriefing after critical events or incidents to maximize learning (Engstrom \& Jones, 2007). Cultural safety and intersectionality were useful frameworks for transforming field education. The literature publishing during this period reflected the interest to place students internationally as well as the need for future research to identify and address practical issues. It was recognized that more social workers with a global worldview were needed (Khan \& Dominelli, 2000). 


\subsubsection{International Practicum Models}

Between 2000-2010, two articles in the results of the literature review addressed international practicum models. Pettys et al. (2005) identified four models of international practicum drawn from a survey that was designed to understand the processes used to place students in international practica. The models of international practicum included: independent/one-time placement model, neighbors-country model, on-site model, and the exchange/reciprocal model. At this time, the authors aimed to inform social work educators and administrators on the need to develop, navigate and evaluate international field placements for students based on the students' needs (Hong \& Song, 2010).

Another study developed a model for the development and continuation of international practica for students to maximize the learning for the student, meet the requirements of the field curriculum, and create a meaningful opportunity for the host country (Maidment, 2003). The international field model included the following aspects: a general overview of the host country, orientation at micro, mezzo, and macro levels, host agency preparation tasks, student preparation tasks, identify gains (for the host and student), finances and costs, clarify expectations, and establish roles for field liaison, students, and supervisor. While an increasing number of social work programs offered international practica, Razack (2002) noted student's frustrations. Lyon's (2006) work on international placements noted the preparatory work required for international placements. Additionally, the concept of reciprocity informed the need to expand beyond the Global North's worldviews to achieve cultural competency (Khan \& Dominelli, 2000).

Additional concerns raised by Barlow (2007) considered how to facilitate a successful field placement in an international context: finding and sustaining partnerships, mutual agreement on learning agreements, language and preparation for placements, monitoring and evaluating the experience, and post-placement debrief. Caragata and Sanchez (2002) identified the crucial importance of engaging with students while they are overseas and providing student support. Supervisors, field coordinators, and other faculty involved in international placements need to support students through regular email and contact, acknowledge the emotional impact, and support students when they feel overwhelmed (Tesoriero, 2006)

\subsection{International Field Placements: 2011-2020}

Based on the results of the literature review, 54 articles, books and doctoral dissertations were identified for the 2011-2020 period (see Table 3). Student learning, placement experiences and outcomes, field models of practicum, and theory are the common topics that are discussed in this era. 
Table 3. Common study areas in 2011-2021

\begin{tabular}{|c|c|c|}
\hline Year & Author & Subject under discussion \\
\hline \multirow{3}{*}{2011} & Schwartz et al. & $\begin{array}{l}\text { This article documents and evaluates formal and } \\
\text { informal preparation of students for an international } \\
\text { social work practicum. }\end{array}$ \\
\hline & Rankopo \& Osei-Hwedie & $\begin{array}{l}\text { This article discusses African perspectives on the } \\
\text { importance of culturally relevant social work practice } \\
\text { and education. }\end{array}$ \\
\hline & Gamble & $\begin{array}{l}\text { This article discusses human rights and social justice, } \\
\text { poverty, and opportunities for economic, social, } \\
\text { political and environmental well-being for all people in } \\
\text { the context of social work. }\end{array}$ \\
\hline \multirow{7}{*}{2012} & Corbin & $\begin{array}{l}\text { This article explores the ethical tensions and dilemmas } \\
\text { that arose for two U.S. social work students during an } \\
\text { 8- month international clinical social work internship in } \\
\text { northern Uganda. }\end{array}$ \\
\hline & Greenfield, Davis \& Fedor & $\begin{array}{l}\text { This study addressed a gap by analyzing data from a } \\
\text { survey of } 122 \text { social work students at Rutgers, the State } \\
\text { University of New Jersey, before and after they } \\
\text { completed (a) a guided study-abroad course. }\end{array}$ \\
\hline & Kreitzer et al. & $\begin{array}{l}\text { The article gives an account of the students' learning } \\
\text { experiences and their evaluation of this program. }\end{array}$ \\
\hline & Jones \& Truell & $\begin{array}{l}\text { The article discusses the challenges to social workers to } \\
\text { help shape the Global Agenda process and the future } \\
\text { strategies of the global bodies. }\end{array}$ \\
\hline & $\begin{array}{l}\text { Nuttman-Shwartz \& Berger } \\
2012\end{array}$ & $\begin{array}{l}\text { A critical review of current knowledge about } \\
\text { international field education and four main aspects are } \\
\text { discussed. }\end{array}$ \\
\hline & Parker et al. & $\begin{array}{l}\text { This article reports findings from a collaborative } \\
\text { international practicum study of UK student learning in } \\
\text { Malaysia. }\end{array}$ \\
\hline & Wiebe & $\begin{array}{l}\text { This article reviews a book published on social work } \\
\text { field education using an anti-oppressive theoretical lens } \\
\text { in Canada. }\end{array}$ \\
\hline 2013 & Sandlin, Wright \& Clark & $\begin{array}{l}\text { How to transform learning experiences in international } \\
\text { field placement into sustainable social work knowledge }\end{array}$ \\
\hline
\end{tabular}


for future practice.

This article highlights the enhanced appreciation of

Bell \& Anscombe international social work, grassroots community development work, cultural diversity, human rights and social justice issues.

This article reports on the International Volunteer Impacts Survey (IVIS) and focuses on international Lough, McBride \& Sherraden service including international contacts, open-mindedness, international understanding, and intercultural relations.

Sossou \& Dubus

This article examines a developing model for building an international social work placement that meets the needs of the host agency and community.

This article identifies potential challenges and issues

Harrison faced by international social work students and cultural capital to successfully complete their practicum.

This article considers pedagogy of conflict oriented

Giles CBR courses in ways to minimize students' experiences of alienating dissonance and enhance learning with diverse perspectives.

This article describes critically reflective techniques

Das \& Anand and providing examples used in a pilot exchange program between a social work school in the UK and in 2014 India.

Crabtree

This study explores how social work students adapt to unfamiliar learning situations in new cultural contexts with the goal of increasing cultural competence.

This article describes a new version of a fieldwork

Nuttman-Shwartz \& Ranz reciprocal working model, which aims to enhance and broaden social workers' perceptions of ISW (International Social Work).

Liley

This article discusses international social work practicum exchanges and study abroad programs, and their unique characteristics.

2015

This article identifies the goals, orientation, planning, Link and outcomes of international social work student exchanges. 
Parker et al.

Roe

Law \& Lee

Cleak, Anand \& Das

2016

Payne \& Askeland

Miles et al.

Ravulo

Thampi

2017

The problematic issue of promoting cultural and intercultural competence through such placements is examined in this article.

The purpose of this doctoral study is to understand the significant experiences within international field practicums and their impact upon the participants.

This article argues to take indigenization as an interactive and non-linear process that helps cultivate a multicultural social work practice.

This study contributes to the literature by exploring the relevance of international field placements for students and drawbacks for them in terms of their careers, employment opportunities and current professional practice

This book explores and questions the concepts of postmodern, international' and' global in light of growing interest in international social work in the early 21 st century.

This research article discusses the concept of transnational partnerships and how these are developed and sustained through international student exchanges.

This article examines Pacific epistemologies, and the experiences of eight Western Sydney University social work students who completed a three-month placement within the islands of Fiji and Samoa.

Opinion research paper supported by literature review that discussed the need for international social work, the challenges involved in international internship and the process and content of field education provided to international students.

This article discusses international internships, cross-cultural perspectives and adaptability, theories of intercultural development, and critical reflection

This article evaluates current social work literature on Matthew \& Lough international field placements and set forth challenges encountered by students.

Nadan

This article suggests a more constructive and reflective view of cultural competence that needs to be adopted in 
order to meet the challenges of international social work.

Fox

Jönsson \& Flem

Jones, Rowe \& Miles

2018 ikolova, \& Sharma

Nuttman-Shwartz \& Ranz

Five lenses of distance are explored to increase the understanding of the student experience: geographical distance, cultural distance, emotional distance, pedagogical distance and technological distance.

This study considers how a sample of students of social work at a large university would embrace cultural competency in international social work prior to working abroad.

The literature highlights the difficulty involved in integrating human rights and social work practice, especially among students who encounter extreme and unfamiliar social problems.

This article explores the four main components developed for the psycho-educational seminar on the traditional field work practicum.

This article examines the need for a critical and global-oriented social work education on students' learning and developments in the context of international field training.

Critical reflection on self and culture to develop intercultural practice skills is discussed and student reflections on the value and impact of these materials are presented in the paper.

Significant multi-layered challenges with delivering quality practicum experiences to social work students are discussed in this article.

In this study experiences in domestic context and analysis based on the experiential learning theories Askeland, Døhlie \& Grosvold inform, and how to transform learning experiences in international field placement into sustainable social work knowledge for future practice

Ranz \& Korin Langer

A model to prepare students for the complexity of international social work is discussed.

Hay et al.
This article explores students' perspectives on the skills, knowledge and capabilities required for international 
placements.

Lanteigne

This doctoral study looks at IFP outcomes for the professional practice of 20 social workers, with half having completed their IFP within five years or less after graduation.

This article explores various issues pertinent to international social work practice and how Western

Ravulo epistemologies affect international placements, barriers to effective placements and student motivations for undertaking practicum away from home.

Fox \& Hugman

This article looks at the models of organizing international placements, in sending or receiving social work students.

This article reflects on the importance of workflow

Henley et al. design for students completing field education as part of a social work degree.

This article draws a critical social work perspective, and

Heron the notion of the "encumbered self," to consider the ethics of international practica.

Zuchowski et al.

Student experiences while learning abroad, students intercultural understanding, and global citizenship are discussed in this article.

This article assesses where and how social work Mapp \& Gatenio Gabel programs are teaching students about international practicum.

The core principles of social work and responses to

Sewpaul \& Henrickson calls to decolonize social work in the context of the increasing regulation of social work are discussed in this article.

Vassos

The empirical research on how policy directions have impacted field education is discussed in this article.

This article reports on professional identity and skill

Willis et al. development for 25 U.S. Latinx students who completed internships or service-learning projects in Costa Rica.

2020. Caron

This article presents a model to develop a framework that includes international social work as a 
specialization within the generalist social work curricula.

Jönsson \& Flem

This article examines the influence of and need for a critical and global-oriented social work education on students' learning and training.

\subsubsection{Student Learning, Practicum Experiences, and Outcomes}

In the literature reviewed for 2010-2020, international social work education and training considerations were found. Careful preparation for international practica was identified as vital to ensure a positive experience for both the student and the community in which they worked. It was suggested that preparation for an international practicum should include a well-structured curriculum and adequate pre-departure cultural training, supervision, and other supports that promote greater intercultural understanding and enhance students' ability to work across cultural groups (Dunlap \& Mapp, 2017). Personal planning, such as assisting students with emotion management, finances, legal requirements, and culture shock, were also considered as critical aspects of preparation (Fox, 2017; Schwartz et al., 2011). According to Kreitzer et al. (2011) there were two forms of international practicum preparation: formal and informal. Formal training was organized and typically delivered in a classroom such as language classes. Simultaneously, informal preparation was less organized and was provided as needed, such as travel information or information shared between students (Sandlin et al., 2013).

\subsubsection{Ethical Dilemmas and Tensions}

During this period, various ethical dilemmas and tensions faced by students who participated in an international placement were highlighted. For example, Corbin (2012) discussed that students can feel emotional discomfort due to personal beliefs being challenged as a result of differences in relationships, cultural norms, beliefs, and expectations (Henley et al., 2019; Parker, 2015). Discussions of experiences and reflecting on and contextualizing the ethical dilemma were found to help alleviate this challenge. Matthew and Lough (2017) identified nine challenges in international field placements that can be divided into two subcategories of personal and institutional challenges (Lough et al, 2013; Ravulo, 2016). Personnel challenges included barriers in language and communication, disparities in cultural values, culture shock, and identity conflicts. Institutional challenges were found to include insufficient pre-departure preparation, insufficient support and supervision, inadequate international field education structure, discrepancies in conceptualizations of social work practice, and a lack of re-entry assistance (Lanteigne, 2018; Miles et al. 2016; Ravulo, 2016).

Some articles promoted critical reflection in preparing for international practicum, especially in a pre-departure course. A common sentiment of the period is that if one does not understand their worldview and cultural identity, they may interpret their own experiences as the norm rather than recognizing it as one of many worldviews (Dunlap \& Mapp, 2017; 
Sewpaul \& Henrickson, 2019). Authors recommended that students must consider their social location, the history between their home country and the country to which they will travel, and the needs of those they will support (Liley et al., 2015; Ravulo, 2018). The key concerns of international practicum programs during this period included academic training, developing curriculum, cultural hegemony, cross-cultural competence, applied research in training and practice, and social activism (Caron, 2020). According to Caron (2020), there are three foundations of practice to consider in the development of an international social work program, 1) anti-imperialist practice frameworks that include understanding colonialism; 2) anti-oppressive practice perspective which promotes equity, inclusion, change, and social justice by focusing on various aspects of oppression, discrimination, and structural power dynamics; and 3) critical approach to practice that entails understanding one's own beliefs, privileges, power dynamics, and oppressions.

According to Jönsson and Flem (2018), students' narratives often included a 'Third World' development discourse that needs to be challenged by preparing students for international practica through critical and postcolonial knowledge. Rankopo and Osei-Hwedie (2011) proposed that curriculum development must involve student collaboration to enhance self-reflexivity and awareness of their West-centric perspectives, privileges, and the global postcolonial context. Further, Law and Lee (2016) suggested that it was essential to note that Indigenization, defined as cultivating culturally relevant social work for ethnic minority communities, can help foster multicultural social work practice within a country. However, when implementing this practice, the involvement of ethnic groups in establishing their social work practice should take precedence (Parker et al., 2015). Essentializing ethnicity and culture need to be avoided; values and practices that foster interaction and mutual respect among ethnic groups should be prioritized. Importing Western values and practices to assist marginalized ethnic groups may result in new forms of inequity (Greenfield et al., 2012; Law \& Lee, 2016).

\subsection{International Practicum Models}

In the second decade, international placements models were found to be the same as cited by Pettys et al. (2005): the independent one-time model, neighbor-country model, on-site group model, and the exchange/reciprocal model (Cleak et al., 2016). Field placements were guided by experiential learning theory, which incorporates practice and theory by helping students become reflexive (Askeland et al., 2018). Reflexivity in international field placements was particularly important given the new culture and context that students were exposed to. Transformative learning was also reflected in international field placements. The learner is central to the development process, particularly since it was common for there to be no onsite university faculty liaison to support students in their international placement (Sandlin et al., 2013). Transformative learning is a significant learning experience that engages the learner intellectually, emotionally and socially (Giles, 2014). Transformative learning is considered a critical component of international field placement that helps learners grow and integrate knowledge from their experience (Askeland et al., 2018). The importance of language and preparation for international practicum was also noted during this decade, calling for formal preparations. Schwartz et al. (2011) shared four preparatory models that can be used for 
students who are considering international practicum that included interviews, orientation-based seminars, audio-visual materials, readings and language courses to assist in the field planning and preparatory process (Healy \& Thomas, 2020).

The review of the literature reflects several innovative approaches. Thampi (2017) proposed a general model of international field education that supports a two-way exchange of knowledge shaped by the home and host institution. It was increasingly recognized that professional knowledge developed in the context of western paradigms needed to be combined with local approaches. Sossou and Dubus (2013) examined a developing model for building an international social work placement that meets the needs of the host agency and community first. Ranz and Korin Langer (2018) argued for a framework that includes an international practicum specialization built within a generalist undergraduate social work curriculum. The model/framework that was included in this article refers to the researcher/educator/practitioner triad and was often used for the training and development of international field placements. The same source presented the cornerstones guiding the development of the framework and ISW program and these included "1) critical practice, 2) anti-imperialist practice, and 3) committed and anti-oppressive practice" (Caron, 2020, p. 72). Within these pillars, Willis et al. (2019) highlight some important considerations such as having students understand the impact of colonization, imperialism, and racism, and reflecting upon the concept of white privilege, power, and hegemony within a western model of society. The goal of these three pillars is to move towards a decolonizing pedagogy; to examine the issues that "constitute complex systems of oppression within the very practice" of social work (Caron, 2020, p. 81).

Social work students were guided to address issues on a more global and systemic level (Mapp \& Gabel, 2019). Despite the need for social workers to explore social justice issues on a global level, it was not uncommon for institutions to focus on learning predominantly at the local level (Fox \& Hugman, 2019; Mapp \& Gabel, 2019). Knowing that there were no homogeneous cultures within countries, it was imperative for social workers to develop an understanding of cultural differences and values. Learning from international placements was found to help students to bring cultural knowledge and understanding to their local contexts to better work with diversity and social justice issues that affected marginalized populations (Jones et al., 2019).

Another concern raised during the second decade in the literature was the lack of financial resources available to students to cover travel costs as well as the need for effective field resources to efficiently plan international placements, which were found to pose challenges for sustainability (Zuchowski et al., 2019). With many institutions around the world facing financial constraints, sustainable field placements needed to take into consideration financial constraints, which impact the types of international field placements available to students. For example, institutions that do not have adequate funding for students to attend full semester international placements may need to consider shorter placements or online field placements (Ranz \& Korin Langer, 2019). 


\subsection{Challenges and opportunities}

Consistent with the literature from the 2000-2010 timeframe, international field placements continued to pose challenges and opportunities for students in 2011-2020. Despite new innovative models in international field placements, there were continued challenges that existed with organizing placements, supporting students, addressing financial obstacles and barriers, and identifying qualified supervisors (Bell \& Anscombe, 2013). These findings are corroborated and expanded upon by other studies that document barriers such as language, application of theory and frameworks, and practical difficulties (money, health, safety, accommodation, and travel) (Cleak et al., 2016). Additionally, students raised concerns regarding safety issues that encompassed overall health and wellbeing, and that the risk and safety of students were considered complex and needed to be addressed to ensure a more enjoyable experience for students going abroad (Zuchowski et al., 2019).

Notwithstanding challenges, international field placements were found to provide transformative learning opportunities for social work students (Wiebe, 2012). Motivation for students to complete international placements stemmed from the desire to work more closely with international organizations with a common interest or based on personal connections (Heron, 2019). International study experiences were found to have a significant positive impact on student learning, student group cohesion, professional commitment, and motivation as well as an enhanced appreciation of international social work, grassroots community development work, cultural diversity, human rights and social justice issues (Bell $\&$ Ansconbe, 2013).

\section{Discussion}

Over the last two decades the focus of academic literature about international social work field education has shifted from a perspective of methods, models and how to make international practicums work for students to a more critical focus on globalization, reciprocity, and incorporating anti-oppressive practice and cultural humility. There is a shift or evolution from a how-to perspective, to a why and who and what, critical evaluation perspective.

Findings from the last two decades of research show the growing emphasis on co-creation of knowledge and shared and reciprocal learning as tools to combat imperialism and oppression in international practica and international social work education (Caron, 2020; Jonsson \& Flem, 2020; Patterson, 2019). This literature points to the opportunity for international practica to be a tool to decrease ethnocentricity and cultural hegemony of social workers by enhancing self-awareness and cultural sensitivity. Due to the history of imperialism in social work, it is critical to emphasize anti-imperialism and the co-creation of knowledge through dialogue to all students and instructors engaging in international field education (Caron, 2020; Patterson, 2019).

Literature from the last two decades supports the potential of students experiencing culture shock in response to feelings of anxiety and confusion about their own Westernized beliefs when they participate in an international placement (Barlow, 2007; Matthew \& Lough, 2017). 
In the case of international field education, students experience a feeling of otherness (Barlow, 2007; Crabtree et al., 2014). Power imbalances that are normally experienced by cultural minorities are encountered by students as they experience new cultural experiences. Value conflicts can occur as students try to rectify contentions that may occur between Western ideologies and those experienced in non-Western cultures (Ranz \& Korin Langer, 2018). Financial constraints continue to pose challenges for international field placements. This also impacts opportunities for reciprocal international practicum relationships between nations.

\section{Conclusion}

Globalization and internationalization have changed the world. Societies, cultures, systems, and institutions are now well connected with each other. The role of international organizations, global policies, and the emergence of uniform agendas (SDGs) have created opportunities for social work to play a more active role on the world stage. There are global social challenges to be addressed such as inequities and inequalities, human rights violations, international development issues, impacts of climate change, environmental degradation, and an increase in environmental disasters, to name a few. Social workers promote human rights and social, economic, and environmental justice. There is a continued need to understand, discuss and initiate international practicum opportunities in social work schools. An international practicum can provide students with opportunities to learn about diverse cultural contexts, world views, global agendas, and complex challenges facing local and global communities.

The review of the published literature shows that different models of international practice have been used, with more discussion and engagement on this topic since 2010. Many social work schools are preparing to expand practicum opportunities for students to work in diverse contexts (Cwikel et al., 2010). In Canada, a recent survey found that many social work education programs would like to develop international practicum opportunities for undergraduate and graduate students, or expand their offerings (TFEL, 2021). More innovative, creative, and sustainable approaches of field education are required to advance the profession in this era. The Transforming the Field Education Landscape (TFEL) project is developing an International Practicum Training Module to better prepare students and field educators for international practicum. The module will explore promising practices in international practicum, and discuss supervision, ethical issues, globalization, cultural diversity and humility, and anti-colonial and anti-oppressive theories of relevance for international field education.

\section{Acknowledgements}

The authors are members of the Transforming the Field Education Landscape (TFEL) project. We wish to acknowledge the contributions of student research assistants Monica Franco Baquero, Tara Collins, Ellen Mi, Shivani Samra, Dillon Traber, Elladee Windsor, Nicole Brown, Andrea Silva Santisteban and Ying Yang in the project. The TFEL project is supported in part by funding from the Social Sciences and Humanities Research Council. 


\section{References}

Ali, W., \& Drolet, J. (2021) Field education and practice research. The Advocate, 46(2), 33-35.

Askeland, G. A., Døhlie, E., \& Grosvold, K. (2018). International field placement in social work: Relevant for working in the home country. International Social Work, 61(5), 692-705. https://doi.org/10.1177/0020872816655200

Ayala, J., Drolet, J., Fulton, A., Hewson, J., Letkemann, L., Baynton, M., ... \& Schweizer, E. (2018). Field education in crisis: Experiences of field education coordinators in Canada. Social Work Education, 37(3), 281-293. https://doi.org/10.1080/02615479.2017.1397109

Barlow, C. A. (2007). In the third space: A case study of Canadian students in a social work practicum in India. International Social Work, 50(2), 243-254. https://doi.org/10.1177/0020872807073990

Bell, K. \& Anscombe, A. W. (2013). International field experience in social work: Outcomes of a short-term study abroad programme to India. Social Work Education, 32(8), 1032-1047. https://doi.org/10.1080/02615479.2012.730143

Caragata, L., \& Sanchez, M. (2002). Globalization and global need: New imperatives for expanding international social work education in North America. International Social Work, 45(2), 217-238. https://doi.org/10.1177/00208728020450020201

Caron, R. (2020). Anti-imperialist Practice and Field Placements "Researcher/educator/practitioner" Model for International Social Work Practice. Journal of Teaching in Social Work, 40(1), 71-85. https://doi.org/10.1080/08841233.2019.1694619

Corbin, J. (2012). Ethical tensions and dilemmas experienced in a Northern Ugandan social work internship. Journal of Social Work Education, 48(4), 817-836. https://doi.org/10.5175/JSWE.2012.201100136

Cleak, H., Anand, J., \& Das, C. (2016). Asking the Critical Questions: An Evaluation of Social Work Students' Experiences in an International Placement. British Journal of Social Work, 46(2), 389-408. https://doi.org/10.1093/bjsw/bcu126

Crabtree, S., Parker, J., Azman, A., \& Carlo, D. (2014). Epiphanies and learning in a postcolonial Malaysian context: A preliminary evaluation of international social work placements. International Social Work, 57(6), 618-629. https://doi.org/10.1177/0020872812448491

Crabtree, S., Parker J., Azman A., \& Mas'ud F. (2014). A sociological examination of international placement learning by British social work students in children's services in Malaysia. Journal of Comparative Research in Anthropology and Sociology, 5(1), 133.

Cwikel, J., Savaya, R., Munford, R. and Desai, M. (2010). Innovation in schools of social work: An international exploration. International Social Work, 53(2), pp. 187- 201. https://doi.org/10.1177/0020872809355393 
Das, C., \& Anand, J. C. (2014). Strategies for critical reflection in international contexts for social work students. International Social Work, 57(2), 109-120. https://doi.org/10.1177/0020872812443693

Dominelli, L. (2010). Globalization, contemporary challenges and social work practice. International Social Work, 53(5), 599-612. https://doi.org/10.1177/0020872810371201

Dunlap, A., \& Mapp, S. C. (2017). Effectively preparing students for international field placements through a pre-departure class. Social Work Education, 36(8), 893-904. https://doi.org/10.1080/02615479.2017.1360858

Engstrom, D., \& Jones, L. P. (2007). A broadened horizon: The value of international social work internships. Social Work Education, 26(2), 136-150. https://doi.org/10.1080/02615470601042631

Fox, M. (2017). Student isolation: the experience of distance on an international field $\begin{array}{llll}\text { placement. Social Work 508-520. } & \text { 36(5), }\end{array}$ https://doi.org/10.1080/02615479.2016.1215418

Fox, M., \& Hugman, R. (2019). International field placements: The models Australian social work programmes are currently using. International Social Work, 62(5), 1371-1383. https://doi.org/10.1177/0020872818767252

Gamble, D. N. (2011). Advanced concentration macro competencies for social work practitioners: Identifying knowledge, values, judgement and skills to promote human well-being. Journal of Community Practice, 19(4), 369-402. https://doi.org/10.1080/10705422.2011.625914

Greenfield, E. A., Davis, R. T., \& Fedor, J. P. (2012). The effect of international social work education: Study abroad versus on-campus courses. Journal of Social Work Education, 48(4), 739-761. https://doi.org/10.5175/JSWE.2012.201100147

Ghaffari, A., \& Naderi, M. (2013). The effects of globalization on Islamic education. International Journal of Management Prudence, 5(2), 7.

Giles, H. C. (2014). Risky epistemology: Connecting with others and dissonance in community-based research. Michigan Journal of Community Service Learning, 20(2), 65-78.

Harrison, G., \& Ip, R. (2013). Extending the terrain of inclusive education in the classroom to the field: International students on placement. Social Work Education, 32(2), 230-243. https://doi.org/10.1080/02615479.2012.734804

Henley, L., Lowe, S., Henley, Z., Munro, C. (2019). Overseas social work placements: Can a well-designed workflow increase the success of an overseas placement? Aotearoa New Zealand Social Work, 31(2), 69-76. https://doi.org/10.11157/anzswj-vol31iss2id634

Heron, B. (2019). Critically considering international social work practica. Critical Social Work, 7(2). https://doi.org/10.22329/csw.v7i2.5737 
Hay, K., Lowe, S., Barnes, G., Dentener, A., Doyle, R., Hinii, G., \& Morris, H. (2018). 'Times that by 100': Student learning from international practicum. International Social Work, 61(6), 1187-1197. https://doi.org/10.1177/0020872817702707

Healy, L. M., \& Thomas, R. L. (2020). International social work: Professional action in an interdependent world. Oxford University Press.

Hong, P. Y. P., \& Song, I. H. (2010). Glocalization of social work practice: Global and local responses to globalization. International Social Work, 53(5), 656-670. https://doi.org/10.1177/0020872810371206

Johnson, A. K. (2003). Increasing internationalization in social work programs: Healy's continuum as a strategic planning guide. International Social Work, 47(1), 7-23. https://doi.org/10.1177/0020872804036445

Jones, D. N., \& Truell, R. (2012). The global agenda for social work and social development: A place to link together and be effective in a globalized world. International Social Work, 55(4), 454-472. https://doi.org/10.1177/0020872812440587

Jönsson, J. H., \& Flem, A. L. (2018). International field training in social work education: beyond colonial divides. Social Work Education, 37(7), 895-908. https://doi.org/10.1080/02615479.2018.1461823

Jönsson, J. H., \& Flem, A. L. (2020). Global social work ethics and international field training: The experiences and practice dilemmas of Norwegian and Swedish social work. International Social Work, 1 - 14. https://doi.org/10.1177/0020872819889398

Karadagli, E. C. (2012). The effects of globalization on firm performance in emerging markets: Evidence from emerging-7 countries. Asian Economic and Financial Review, 2(7), 858 .

Kreitzer, L., Barlow, C., Schwartz, K., Lacroix, M., \& Macdonald, L. (2012). Canadian and EU social work students in a cross-cultural program: What they learned from the experience. International Social Work, 55(2), 245-267. https://doi.org/10.1177/0020872811427047

Khan, P., \& Dominelli, L. (2000). The impact of globalization on social work in the UK. European Journal of Social Work, 3(2), 95-108. https://doi.org/10.1080/714052817

Lanteigne, I. (2018). The International Field Placement Experience: A Continuous Process with Learning Moments and Outcomes. Doctoral $(\mathrm{PhD})$ thesis, Memorial University of Newfoundland. https://research.library.mun.ca/13623/

Law, K. Y., \& Lee, K. M. (2016). Importing Western values versus indigenization: Social work practice with ethnic minorities in Hong Kong. International Social Work, 59(1), 60-72.

https://doi.org/10.1177/0020872813500804

Liley, D. G. (2015). Sherpa in my backpack: A guide to international social work practicum exchanges and study abroad programs. Social Work Education, 34(3), 359-360. https://doi.org/10.1080/02615479.2015.1005994 
Link, R. (2015). International social work student exchanges. International Encyclopedia of the Social \& Behavioral 5ciences, 562-567. https://doi.org/10.1016/b978-0-08-097086-8.28049-5

Lough, B., (2009). Principles of effective practice in international social work field placements. Journal of Social Work Education, 45(3), 467-479. https://doi.org/10.5175/JSWE.2009.200800083

Lough, B. J., McBride, A. M., \& Sherraden, M. S. (2012). Measuring international service outcomes: Implications for international social work field placements. Journal of Social Work Education, 48(3), 479-499. https://doi.org/10.5175/jswe.2012.201000047

Lyons, K. (2006). Globalization and social work: International and local implications. British Journal of Social Work, 36(3), 365-380. https://doi.org/10.1093/bjsw/bcl007

Maidment, J. (2003). Problems experienced by students on field placement: Using research findings to inform curriculum design and content. Australian Social Work, 56(1), 50-60. https://doi.org/10.1046/j.0312-407X.2003.00049.x

Mapp, S. \& Gatenio Gabel, S. (2019). Educating students on international social work issues in U.S. social work programs: How is it done? Journal of Social Work Education, 55(2), 238-250. https://doi.org/10.1080/10437797.2018.1513881

Matthew, L. E., \& Lough, B. J. (2017). Challenges social work students encounter in international field placements and recommendations for responsible management. Journal of Social Work Education, 53(1), 18-36. https://doi.org/10.1080/10437797.2016.1246268

McMichael, A. J. (2013). Globalization, climate change, and human health. New England Journal of Medicine, 368(14), 1335-1343. https://doi.org/10.1056/NEJMra1109341

Miles, D., Jones, P., Gopalkrishnan, N., Francis, A., Harris, N., Howard, E., King, J., Zuchowski, I., Dhephasadin N. P., \& Puthantharayil, G. (2016). Contested concepts of 'partnership' in international student exchange programs. Research and Development in Higher Education: The Shape of Higher Education, 39, 202-211. Retrieved from https://researchonline.jcu.edu.au/44590/

Nadan, Y. (2017). Rethinking 'cultural competence' in international social work. International Social Work, 60(1), 74-83. https://doi.org/10.1177/0020872814539986

Numann -Shwartz, O., \& Berger, R. (2012). Field education in international social work: Where we are and where we should go. International Social Work, 55(2), 225-243. https://doi.org/10.1177/0020872811414597

Nuttman-Shwartz, O., \& Ranz, R. (2017). Human rights discourse during a short-term field placement abroad: An experience of social work students from Israel and India. International Social Work, 60(2), 283-296. https://doi.org/10.1177/0020872815598568 
Parker, J., Crabtree, S. A., Baba, I. B., Carlo, D. P., \& Azman, A. (2012). Liminality and learning: International placements as a rite of passage. Asia Pacific Journal of Social Work and Development, 22(3), 146-158. https://doi.org/10.1080/02185385.2012.691715

Parker, J., Crabtree, S. A., Azman, A., Carlo, D. P., \& Cutler, C. (2015). Problematising international placements as a site of intercultural learning. European Journal of Social Work, 18(3), 383- 396. https://doi.org/10.1080/13691457.2014.925849

Pawar, M., Hanna, G., \& Sheridan, R. (2004). International social work practicum in India. Australian Social Work, 57(3), 223-236. https://doi.org/10.1111/j.1447-0748.2004.00150.x

Payne, M., \& Askeland, G. A. (2016). Globalization and international social work: Postmodern change and challenge. Routledge. https://doi.org/10.4324/9781315585093

Pettys, G. L., Panos, P. T., Cox, S. E., \& Oosthuysen, K. (2005). Four models of international field placement. International Social Work, 48(3), 277-288. https://doi.org/10.1177/0020872805051705

Rankopo, M. J., \& Osei-Hwedie, K. (2011). Globalization and culturally relevant social work: African perspectives on indigenization. International Social Work, 54(1), 137-147. https://doi.org/10.1177/0020872810372367

Ranz, R. (2017). A psycho-educational learning framework for international field work abroad. International Social Work, 60(4), 954-965. https://doi.org/10.1177/0020872815594227

Ranz, R. \& Langer, N. K. (2018). Preparing international social work students to engage with unequal power relations. Social Work Education, 37(4), 535-545. https://doi.org/10.1080/02615479.2018.1444158

Ravulo, J. (2018). Australian students going to the Pacific Islands: International social work placements and learning across Oceania. Aotearoa New Zealand Social Work, 30(4), 56-69. https://doi.org/10.11157/anzswj-vol30iss4id613

Ravulo, J. (2016). Pacific epistemologies in professional social work practice, policy and research. Asia Pacific Journal of Social Work and Development, 26(4), 191-202. https://doi.org/10.1080/02185385.2016.1234970

Razack, N. (2002). A critical examination of international student exchanges. International social work, 45(2), 251-265. https://doi.org/10.1177/00208728020450020801

Roe, E. P. (2015). Exploring the influence of international social work practicums on career choices and practice approaches. Doctoral $(\mathrm{PhD})$ thesis, Memorial University of Newfoundland. https://research.library.mun.ca/9735/

Sandlin, J. A., Wright, R. R., \& Clark, C. (2013). Reexamining theories of adult learning and adult development through the lenses of public pedagogy. Adult education quarterly, 63(1), 3-23. https://doi.org/10.1177/0741713611415836 
Sewpaul, V., \& Henrickson, M. (2019). The (r)evolution and decolonization of social work ethics: The Global Social Work Statement of Ethical Principles. International Social Work, 62(6), 002087281984623-1481. https://doi.org/10.1177/0020872819846238

Schwartz, K., Kreitzer, L., Lacroix, M., Barlow, C. A., McDonald, L., Lichtmannegger, S., ... \& Meunier, D. (2011). Preparing students for international exchanges: Canadian/EU experiences. European Journal of Social Work, 14(3), 421-434. https://doi.org/10.1080/13691457.2010.488213

Song, K., (2016). Multicultural and international approaches in social work practice: An intercultural perspective. Hamilton Books.

Small, E., Nikolova, S. P., \& Sharma, B. B. (2017). Cultural competency in the global setting: Are social work students prepared to serve in a culturally diverse world? British Journal of Social Work, 47(3), 666-682. https://doi.org/10.1093/bjsw/bcw050

Thampi, K. (2017). Social work education crossing the borders: A field education programme for international internship. Social Work Education, 36(6), 609-622. https://doi.org/10.1080/02615479.2017.1291606

Tesoriero, F. (2006). Personal growth towards intercultural competence through an international field education programme. Australian Social Work, 59(2), 126-140. https://doi.org/10.1080/03124070600651853

Tight, M. (2021). Globalization and internationalization as frameworks for higher education research. Research Papers in Education, 36(1), 52-74. https://doi.org/10.1080/02671522.2019.1633560

Todd, S., \& Drolet, J. (Eds.). (2020). Community Practice and Social Development in Social Work. Singapore: Springer. https://doi.org/10.1007/978-981-13-1542-8

Wittmann, V. (2014). World society and globalisation. Journal for Multicultural Education, 8(3), 194-206. https://doi.org/10.1108/JME-05-2014-0021

Van Wormer, K. (2005). Concepts for contemporary social work: globalization, oppression, social exclusion, human rights, etc. Social Work \& Society, 3(1), 1-10.

Vassos, S. (2019). Challenges facing social work field education. Australian Social Work, 72(2), 245- 247. https://doi.org/10.1080/0312407X.2018.1557232

Wiebe, M. (2012). Shifting sites of practice, field education in Canada. Social Work Education, 31(5), 681-682. https://doi.org/10.1080/02615479.2011.642249

Willis, T. Y., Wick, D., Han, T. M., Rivera, J., \& Doran, J. K. (2019). "If I did it over there, I can do it here": U.S. Latinx social work students in Costa Rican service placements deepening their professional identity and skills. Journal of Social Work Education, 55(4), 710-723. https://doi.org/10.1080/10437797.2019.1611513 


\section{Macrothink}

International Journal of Social Work

ISSN 2332-7278 2022, Vol. 9, No. 1

Zuchowski, I., Miles, D., Howard, E., Harris, N., \& Francis, A. (2019). Sustaining quality learning abroad opportunities in Australian schools of social work. International Social Work, 62(2), 980-993. https://doi.org/10.1177/0020872818757590

\section{Copyright Disclaimer}

Copyright reserved by the author(s).

This article is an open-access article distributed under the terms and conditions of the Creative Commons Attribution license (http://creativecommons.org/licenses/by/3.0/). 